\title{
LINGUAPRAGMATIC ANALYZE OF GREETINGS IN PERSIAN AND UZBEK LANGUAGES
}

CTurdieva Kh., ORCID: 0000-0002-0435-8689,

Alisher Navai Tashkent State University of Uzbek language and literature, Tashkent, Uzbekistan, hulkar.kamilovna@gmail.com

\section{ЛИНГВАПРАГМАТИЧЕСКИЙ АНАЛИЗ ЕДИНИЦ ПРИВЕТСТВИЙ НА ПЕРСИДСКОМ И УЗБЕКСКОМ ЯЗЫКАХ}

\author{
CTурдиева X. K., ORCID: 0000-0002-0435-8689, \\ Ташкентский государственный университет узбекского языка и литературы им. Алишера \\ Навои, Ташкент, Узбекистан, hulkar.kamilovna@gmail.com
}

Abstract. Communication is the important part of the people's life. Communicating way can be the first reason for both success and failure in further progression or regression. Communicating in proper and polite way with the people in different cultural background is becoming one of the most important matters that still lacks researching. Cross-cultural communication happens between two or more people who have different cultural background where the politeness has powerful role. Politeness is the practical application of good manners or etiquette; however, it can vary differently in different culture, namely, what is considered polite in one culture can sometimes be quite rude or unusual in another cultural context. Studying speech etiquette units deeply in one language and comparing them to a particular language can give a great chance to avoid common and uncommon mistakes, misunderstandings and it let learners classify, realize the phrases, words semantically according to certain criteria. In this article, main topic is to study greeting phrases, namely, speech etiquette units comparatively in order to determine the similarities and differences; analyze them lingua-pragmatically considering FTA (face threatening acts) and FSA (face saving acts). Culture differences in greeting behavior of some countries such as Russia, The USA, Italy, Japan, Indonesia, Philippine, China were studied either in order to highlight the actuality of the problem. (e.g. "Sudah mandi?" - "Have you taken a bath?" is totally normal greetings after saying "Selamat pagi"-"Good morning" in Indonesia.) Greeting phrases were collected and analyzed by observation lively, virtually and relying on written, recorded materials, as well as holding a questionnaire survey via google.form. In result, 53 Uzbek greetings, 59 Persian greeting phrases analyzed linguapragmatically in comparative way. Persian people tend to use etiquette units more (no matter sincerely or not) and debasing $1^{\text {st }}$ person (oneself), praising $2^{\text {nd }}$, even $3^{\text {rd }}$ person could bring misunderstanding for Uzbek people. FSA is dominant in Persian where FTA can sometimes be seen in Uzbek speech. Idiomatic phrases are used to strengthen politeness in both languages.

Аннотация. Общение является важной частью жизни людей. Способ общения может быть первой причиной как успеха, так и неудачи в дальнейшей прогрессии или регрессии. Правильное и вежливое общение с людьми принадлежащими к разным культурам становится одним из наиболее важных вопросов которые все еще не изучены глубоко. Межкультурное общение происходит между двумя или более людьми с разными культурными происхождениями, где вежливость играет важную роль. Вежливость - это практическое применение хороших манер или этикета, однако в разных культурах они могут различаться, а именно то, что считается вежливым в одной культуре, иногда может быть довольно грубым 
или необычным в другом культурном контексте. Глубокое изучение единиц речевого этикета на одном языке и сравнение их с конкретным языком может дать отличный шанс избежать ошибок, недоразумений и позволит учащимся классифицировать, понимать фразы, слова семантически в соответствии с определенными критериями. В этой статье основной темой является сравнительное изучение фраз приветствия, единиц речевого этикета, чтобы определить сходства и различия; проанализировать лингва-прагматически, учитывая FTA и FSA. Культурные различия в приветственном поведении некоторых стран, таких как Россия, США, Италия, Япония, Индонезия, Филиппин, Китай были изучены для того, чтобы подчеркнуть актуальность проблемы. (например, «Sudah mandi?» - «Вы принимали ванну?» это совершенно нормальное приветствие после высказывания «Selamat pagi» - «Доброе утро» в Индонезии). Приветственные фразы были собраны и проанализированы путем живого наблюдения и на основе письменных записанных материалов, а также проведения анкетного опроса через google form. В результате 53 узбекских приветствий, 59 персидских приветствующих фраз проанализированы лингвопрагматически в сравнительном аспекте. Иранцы, как правило, используют этикеты чаще (независимо от того, искренни они или нет) и унижать 1-го лица (самого себя), восхваление 2-го и даже 3-го лица может вызвать недопонимание для узбекского народа. FSA является доминирующим на персидском, где FTA иногда можно увидеть в узбекской речи. Идиоматические фразы используются для усиления вежливости на обеих языках.

Keywords: lingua-pragmatics, speech etiquette units, Persian, Uzbek, politeness, face.

Ключевые слова: лингвопрагматика, единицы речевого этикета, персидский, узбекский, вежливость, лицо.

\section{Introduction}

Speech etiquette is connected with nation's culture, mentality, feelings, religion and activity. Research on this topic plays an important role to choose appropriate units in cross-cultural communication. As I.Romanova states [1] speech etiquette refers to special cultural rules and speech politeness which consists of communication norms. In each language, there are common principles, etiquette formulas, and speech rules in the situational conversations such as greeting, parting, asking apology, thanking, complimenting and so forth. We suppose that lingua-pragmatic research on this topic comparatively in two or more languages can give a chance for each language's representative to understand one another's culture, mentality, beliefs, customs, and appreciations deeply as well as they do not often pragmatic mistakes during the mutual communication. On studying this theme, one can realize how the factors such as nation, nation's language, gender, age, social status, career degree, ethnic origin, economical life and religion have a strong influence in our speech.

Lingua-pragmatics studies the importance of the connection between social norms and language. It includes sociology partly and linguistics partly. As Levinson [2] reminds, Sociopragmatics learns theoretical studies on social connotation, behavior, mentality; Pragma-linguistics learns linguistic rules and norms which relate to social language. Lingua-pragmatics learns linguistic and social norms very connectively.

Lingua-pragmatics is the talent of using language correctly in order to achieve the aims that belong to only humanity. As Iranian researcher Dr. Nafez says "It is the study of the fixed forms of a language that have fixed socio-pragmatic values in actual verbal communication" [3].

Scientific journal of Moscow state university of Linguistics gives definition to Linguapragmatics as follows: 
It is still new topic that researchers started investigating from the second half of the past century. Lingua-pragmatics is connected with semantics, stylistics, rhetoric, and communicative syntax, theory of discourse and partly psycholinguistics as well as sociolinguistics. The problem area of this topic is not very clear. Lingua-pragmatics studies the aim of the speaker and speaker's attitude to the addressee.

It studies following questions:

-theory of speech acts, aim of speech and kinds of speech acts;

-rules of having conversation, significances of speech etiquette;

-unclear opinion, satire, reported speech acts;

- discourse questions.

Leech states that Lingua-pragmatics is between Pragma-linguistics and Socio-pragmatics [4]. He explains Lingua-pragmatics with following table [3]:

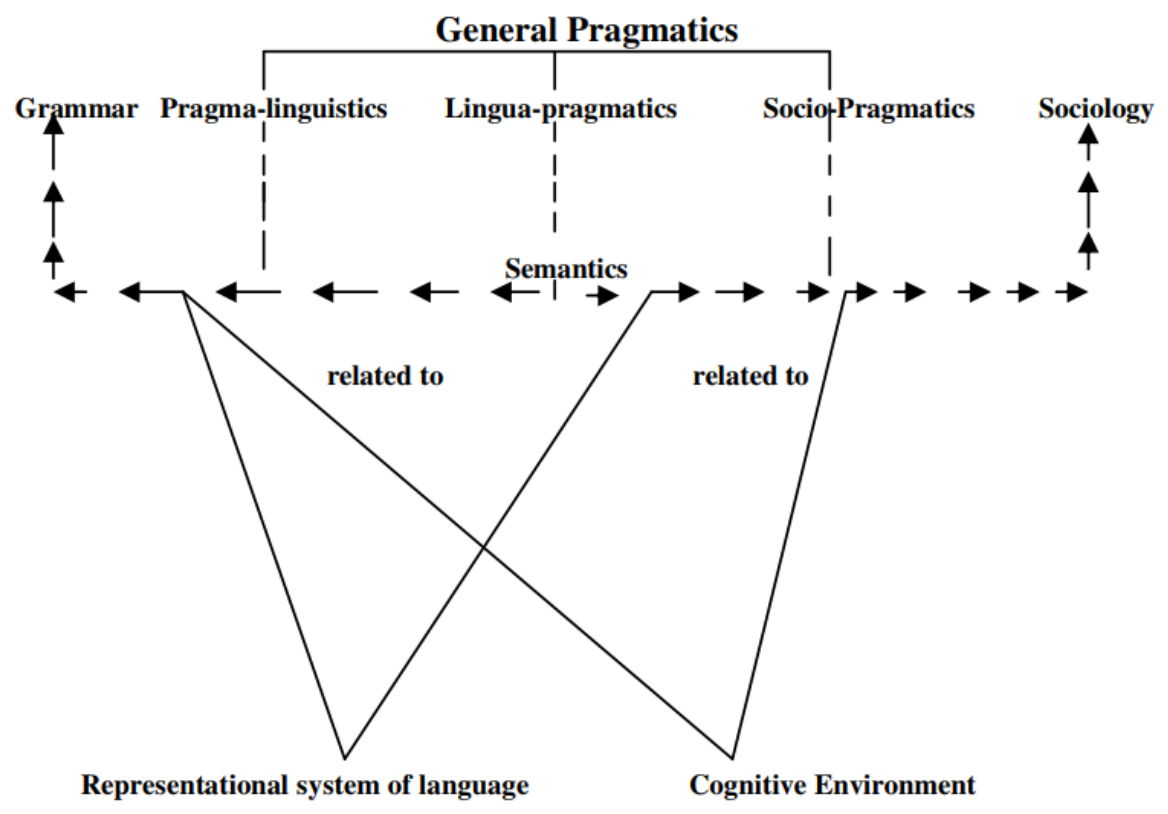

Lingua-pragmatics makes necessary chain between two main components of verbal speech. Lingua-pragmatics indicates language system and speaker's adaptation in cognitive atmosphere. This part of pragmatics does not match with any other parts. Furthermore, pragma-linguistics checks grammar errors more. For example, direct translation from Arabic into English is reminded in Dr Nafez's research. "I wrote for him a letter" In this case, speaker means "I have sent him a letter" By changing grammar, semantic change also may occur. Socio-pragmatics is more connected with sociology and studies social norms and speech behavior. Semantics is connected with pragmalinguistcs, as well as lingua-pragmatics and separated from them. However, semantics has closer relationship with pragma-linguistics. In lingua-pragmatics linguistic forms have already been created for particular situations. Speaker is not so independent to use own words, creativity as a speech etiquette units as it can cause misunderstanding. Lingua-pragmatic mistakes are observed in expressing greetings, congratulations, compliments, empathy, sympathy, wishing, hesitation and so forth.

Investigating FTA and FSA is also significant in lingua-pragmatic research. As Wilson [4] states: Positive face refers to friendliness and empathy among the people, whereas negative face identifies social distance and freedom of pressure- FTA (face threatening acts). Therefore, most greeting phrases can be noted as positive face and included in FSA (face saving acts).

\section{Material and research methods}

Research is based on the following sources: 
-Theoretical sources;

-Mass media materials (newspaper, magazines, TV programs, films, internet);

-Fiction works;

-Interview with Iranian and Uzbek people;

-Questionnaire survey on "Greeting politeness" in each culture.

https://docs.google.com/forms/d/e/1FAIpQLScLuTN9XtMZYCx6yO1RUXQhoTSpiHLWoke GoJsk2CMLgmrWpA/viewform?usp=sf_link

Place: Uzbekistan

Method:

- Data collection: a) Observation b) Questionnaire

- Data analysing: a) Individual site analysing b) Cross-cultural analysing

FTA (face threatening acts) and FSA (face saving acts) are also defined in the findings.

\section{Results and discussion}

The results of the work are described extremely accurately and informatively.

The main theoretical and experimental results, actual data, discovered relationships and regularities are presented. At the same time, preference is given to new results and long-term data, important discoveries, conclusions that refute existing theories, as well as to data that, in the author's opinion, are of practical importance.

Verbal politeness has crucial role in each nation's culture. As Jiang Zhu states, "In crosscultural communication, cultural differences play an important role in speech act in the disciplines in use of speech. Moreover, people tend to use the principles of their own culture as the standard to explain and evaluate other people's behaviour. This is what is called "pragmatic transfer". Due to this, pragmatic failure occurs easily and the cross-cultural communication is blocked." [5] For instance, for Persian, Uzbek as well as Central Asian, South Asian and Far Eastern people using verbal politeness according to mentioned criteria's is believed to be compulsory act in order to save face (willingly or unwillingly). However, in more western culture, such as American, Russian and etc. do not accept overstated polite words, self-debasing and sacrificing own wishes, too much respect towards other can sound as fake or artificial relationship. There is a phrase in Russian "Vejlivost - serdechnost" which means politeness should be from the heart. Russian people cannot accept too much praise or compliments and responding them respectively.

Uzbek and Persian people use speech etiquette phrases every day in order to keep friendly atmosphere among people.

Our research's topic - Greetings plays and affective role in creating friendly and smooth relationship or communication. As each culture owns special speech acts, it needs deeper studying.

Speech etiquette is crucial topic to study daily life, culture of the each nation. There are some examples for variety of speech etiquette in various cultures. Asking the question "Where are you going?" from not very close people can be accepted as a short continue of the greeting in Uzbek, whereas in some Western countries and Far East it can be sounded as interfering in privacy. In Indonesia during the conversation of greeting asking the question "Sudah mandi" - "Have you taken a bath?" is totally normal for Indonesian people and they mean closer greeting by that. According to particular surveys, when this question is given to a foreigner he/she can have unpleasant image or suspect about own odor, thinking “Am I smelling bad?!” In Vietnam people greet each other saying "Have you eaten rice today?" In Southern China, Philippine, Thailand we can hear greetings as "Did you eat?" [6]. Phrases in different cultures own special meaning and it is connected with mentality and lifestyle of the nation. As Indonesia is tropical country, one get sweaty very often. Feeling fresh after taking bath or shower is pleasant condition. Therefore, instead 
of "Are you Ok?" it is better and means friendliness asking "Have you taken bath?". In other Asian countries being full, not being hungry is pleasant condition.

In many foreign languages in order to express greetings, people use parts of the day or time in their speech. I English, "Good morning", "Good afternoon", "Good evening" means starting of conversation, whereas "Goodnight" means parting greeting. In Persian, there is an equivalent of “goodnight" - "شب بخير Which can be translated as starting the communication or finishing it. As Akbar Ahfari states When Persians meet for the first time, there is similar expression for the occasion Xoshvaghtam or Az ashenaee ba shoma Xoshvaghtam), often accompanied by body language such as nodding, smiling and shaking hands too. In Uzbek culture, including these gestures, there is a gesture - placing right hand on left chest meaning "I am happy from my heart". Besides that, we could observe numerous variations of greetings in both languages.

Having researched on "greeting politeness", namely, "saying hello" several interesting facts and new nuances were determined. Number of Uzbek greeting units reached to 53, Persian one reached to 59 . We will try to analyze and compare lingua-pragmatically some important ones of them.

Australian linguist Halliday (1979) suggests to divide greetings into two groups: Time-bound greetings and Time-free greetings [5].

We divided Time-bounded greetings into following groups: A) Daily greetings B) Seasonal greetings.

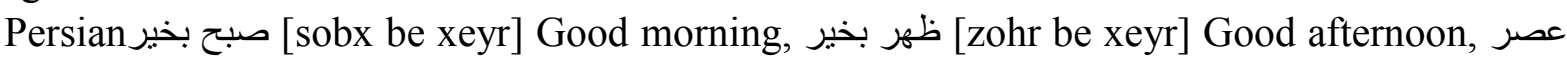
بخير [asr be xeyr] Good evening — greeting words' Uzbek translations are hayrli tong, hayrli kun, hayrli kech. But, in the result of interviews and observing alive, also written sources, we came to determination that in Persian those units express positive face, whereas in Uzbek it refers to negative face. In other words, use of time bounded greetings in Persian means respect or sincere relationship, while it can sound as distance relationship and insincere, formal attitude in Uzbek culture. No matter what part of the day it is, in Uzbek language Arabic loanword"Assalamu

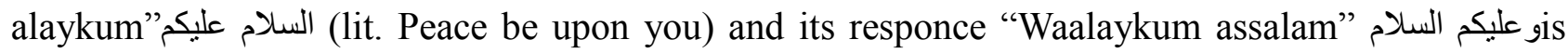
used widely instead of saying Goodmorning/Hello and so on. And it is always used in both formal and informal situations expressing positive face. In Persian language this loanword has changed phonetically and became "Salam alaykom" سلام عليكم (skipping article "al") and used in particular cases, whereas "Salam" سـام- short version of "Assalamu alaikum" is usual salutation used in Iranian conversations. In Wikipedia it was mentioned as "Salam alaikom" is a somewhat formal Islamic greeting in Persian"'[7]. An Iranian user says about these greetings as following:" Al' prefix is reserved for Arabic verses. Using "salam alaykom" people try to show that they are religious, fundamentalist muslim:"(www.quora.com) Therefore, we rarely hear "Salam alaykom" سلام عليكم from Iranian native speakers. This is expressed as a negative face.

[väyt bexeyr] Good day is used in any part of the day and it refers to more formal style [8]. Uzbek version still remains as "Assalamu alaikum". As وقت بخيرs literal translation means "Have a good time" in Uzbek and it is used before parting, saying goodbye especially when some special events are being waited for. In persian language there are stronger and more polite variations of وقتتان بخير such as وقت بخير gäytetan bexeyr] in uzbek "vaqtingiz xayrli bo'lsin" with the meaning of "Have a good time"; and تناب عالى بخى] [väyte jänabe ali bexeyr] "janobi oliylarining وقت سركار vaqtlari hayrli bo'lsin" with the meaning of "I wish Your/His Majesty have a good time; [väyte särkar xanom bexeyr] "boshliq xonimning vaqtlari chog' bo'lsin" with meaning "I wish Your/Her Majesty have a good time". We can see in the example "I wish His Majesty have a good time, $3^{\text {rd }}$ person is used to indicate $2^{\text {nd }}$ person as well as to express respect towards $2^{\text {nd }}$ person. This is usual rule in Persian etiquette speech contexts and observed in everyday life speech either 
expressing positive face, whereas in Uzbek it can sound as an irony or too formality with negative face. Only بخير[värtetan bexeyr] - in uzbek "vaqtingiz xayrli bo'lsin" is the most appropriate phrase which both Uzbek and Persian version own positive face and meaning is the similar. The other Persian phrases mentioned above are preferably not used in daily communications (http://www.amozeshgah-rezvan.blogfa.com/post/21).

If there more people, and you do not have time or desire to greet with each person, the best

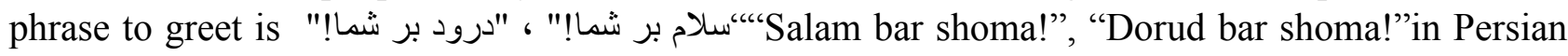
with positive face and it has Uzbek translation "Hammaga salom" (Hello to everyone) with negative face - that is similar meaning with Persian.

In not so formal situations, Uzbek and Persian culture do not limit the conversation with only greetings. Greetings, asking about each other's health, life, activity, news and complimenting, also inviting home and other topics can be not so short or long-lasting conversation as a continue of greetings. As we have observed written and alive sources of our research objects, both native speakers pay attention to politeness using rules, speech etiquette norms very carefully and with responsibility no matter those phrases are sincere or fake in the framework of nation's mentality.

When meeting for the first time, the English say "Nice to meet you" Uzbek people say “Tanishganimdan xursandman”, "Sizni ko'rganimdan xursandman” (I am happy to know/see you); Iranian people از آثناى با شما خوشوقتم [äz aşnaiye şoma xuşväytäm] (I am happy to know you). Other

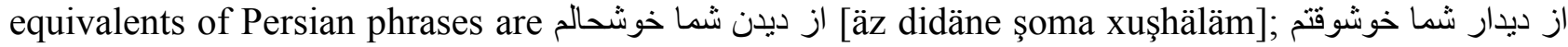

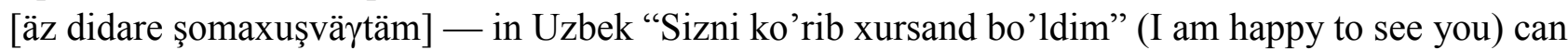
used for the situation as the first meeting or meeting again. They are normally used at the end of the conversation before saying goodbye greetings. Uzbek phrase "Sizni ko'rib xursand bo'ldim" (I am happy to see you) has as same semantic character as Persian ones. They refer to positive face. The respond will be like this: من هم همينطور (Man ham hamintor) — "So am I." By contrast, positive face, high politeness - looking up to interlocutor and debasing oneself principles are observed in Persian whilst using past tense instead of present/future tense is regarded as politeness in Uzbek, but the meaning is not as emotional as in Persian.

In Iranian culture, continue of saying greetings between people who have closer relationship might be as following:

A: “كايين، كم بيدايين" [kojayin käm peydayin] - Where are you? You are seldom seen.

B: "ما زير ياى شماييم" [ma zire paye şomayim] — We are under your feet [9].

In Uzbek culture it sounds like below:

A: Bormisiz? Ko'rinmaysiz? — Do you exist? You are not seen.

B: Yuribmiz-da bir chetda. (panada) - We are just rambling at the corner / under shadow.

It can be seen from examples that self-debasing is stronger in Persian than in Uzbek. In these cases, in both culture positive face (needs to be loved, approved) is at high position. “Oyog'ingiz ostidamiz" We are under your feet — looking up and praising interlocutor mentioning the meaning as "you are greater than me, I am just an ordinate person who can walk under your mercy" can show the real Iranian taarof (speech etiquette). Also, using $1^{\text {st }}$ person in plural instead of $1^{\text {st }}$ person in singular is considered to show respect towards the addresser. This occasion, namely politeness rule of exchanging singularity into plurality belongs to Uzbek culture either.

Not having met for a long time, Persian people say جشم ما روشن [cheshme ma roshan] - "Our eyes are shining" which means "I got happy to see you". In Uzbekistan, people say "Siz kelib, uyimiz (xonamiz) yorishib ketdi" - You have come, our house/room got shiny" that owns almost similar meaning with persian. In both languages, using 1st person in plural instead of singular is one sign of politeness and informing about happiness because of seeing the other person is another sign 
of taarof/politeness. It is difficult to know whether these words are sincere. Positive face is expressed.

Metaphor, allegory, expressiveness, idiomatic phrases can play significant role in strengthening meaning and giving more emotionality to the speech.

The following Persian phrases of "How are you?" are often observed during our research. ج

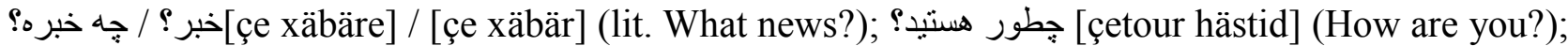
[xub hästid] (Are you good?); شما؟حال/احوال خوب هستيد? [hale şoma] (How is your condition?). Although the responses to these questions can bring some misunderstandings or seem strange for foreigners, these kinds of phrases full of compliment, discourse, self-debasing is the flower of Iranians" speech and Taarof can be called "A business card of Iranian nation".

In the result of investigating oral and written sources, we came to determination that these responses to "How are you?" mentioned below are often seen in natural speech.

[xäbäre sälamäti, xoda ru şokr] (lit. There is news of health, Thanks God) — Thanks God, I am ok/good.

In this response taarof cannot be noticed. It is semantically neutral and direct answer to the question.

[xäbäre xasi nist](lit. There is no special news) -There is nothing new (Persian phrase can be an equivalent to English phrase "There is nothing new under the sun" and its meaning is related to "monotony of life".

خبر تنازه نداريم new.

Both responses seem to be answered directly to the question. However, these responses are used in two different situations. The first situation indicates non-taarof speech, direct answer when person truly does not have any news. In the latter situation a speaker shows modesty. The speaker might have some interesting or happy news. He/she might have succeeded in his/her purpose and so on. Despite having good news, the speaker does not reveal it at once. Even the speaker has a great news, they pretend to be neglecting it as a sign of modesty. Negative face is expressed.

خبرها از شما! Xäbärha äz şoma] (lit. News is from you) It is you who have all the news (http://hamsarekhoob.com/weblog/2/129499).

This type of response means taarof with great respect and apprecation towards the addresser. Having held interviews with Iranian people and relying on both oral and written resources, the following meaning of the phrase خبر ها از شما

"I am just a humble person. Humble, minor people normally do not have interesting news. All the good news is suitable for the perfect and great people like you." Here we can notice positive face via debasing oneself and praising the other part.

If the question asked meaning "How are you?" and there is another person near respondent, the answer is given with speech etiquette considering the other person who is beside the speaker. now)

بbahaş rahätäm] I am good with him/her (I am good, because I am with him/her

In this example, while responding to $2^{\text {nd }}$ person, politeness for the $3^{\text {rd }}$ person is being used. Although the actual definition of باهاش راحتم "Is am good, because I am with him/her now", it does not give meaning of sincerity and sincerity is not expected. If each of the interlocutors is from Iran, they understand well that it is just a overstating, namely Persian culture's main character — taarof.

ab az ab tekan naxoräd] (Water does not touch water) meaning: There is no special news. This idiomaitic phrase is not used so productively in modern Persian speech. It is known as an old unit [11]. 
While asking about the people, e.g. family members, friends and etc. who are not taking part in the conversation, Iranian people have the dialogue like below:

"خوبهستند؟ "Xub hastand?” - “Are they Ok?"

“Alhamdulillah duoguye shoma xastand" — "Alhamdulillah, they always pray for you." Taarof from $3^{\text {rd }}$ person is being sent to $2^{\text {nd }}$ person via $1^{\text {st }}$ person.

In Uzbek the questions meaning "How are you?":

Salomatmisiz? - Are you healthy?

Sog'liqlaringiz yaxshimi? - Is your condition good?

Bardammisiz? - Are you strong?

Baquvvatmisiz? - Are you strong?

Eson-omonmisiz? - Are you healthy and safe?

Charchamasdan yuribsizmi? - Are you living without tiredness?

Qalaysiz? - How are you?

Nima gaplar? What words? - What news?

Nima yangiliklar? - What news?

Zo'rmisiz? — Are you super?

Yaxshimisiz? - Are you Ok?

Qalay endi? - How is it then?

Qalaysiz? - How are you?

Ishlaringiz yaxshimi? - Are your activities good?

Ishlar qalay? - How are your activities?

Tuzukmisiz? - Are you healthy?

When meeting after long time:

Bormisiz? — Do you exist?

Ko'rinmaysiz? - You are not seen.

$100 \$ / €$ lik bo'lib ketdingizku! — You are like \$100/€100.

These questions are asked by order or directly at once. Self-respect needs to be liked are noticed, so positive face is dominant of the questions and answers.

Answers to "How are you?"

Yaxshi rahmat — Good, thanks.

Alhamdulillah shukr - Alhamdulillah, thanks God.

Xudoga shukr rahmat - Thanks God, thanks.

Uncha yangilik yo'q — Not much news.

Yuribmizda bir panada - We are just walking under the shadow.

Rahmat - Thanks.

Sekin - Slowly.

Yuribmiz sekin — We are walking slowly.

Tinchlik - Everything is quiet.

Besides behavioural and etiquette rules, religion has an affection to the speech either. As both countries' main religion is Islam, phrases with meaning of "Thanks Allah", "Thanks God", "Alhamdulillah" are very common [12].

In Persian it is polite to ask about close people who are not participating in the conversation. However, in Uzbek, asking about third person's condition even he /she is taking part in the conversation is sign of polite. For instance, wife, husband and their friend are speaking. Friend: hello, Mr. A. How are you? How is your wife? or vice verse is normal polite situation in Uzbekistan. 

home)

Uydagilar yaxshimi? - Are your family members good? (uydagilar — people who are at

Onangiz/Otangiz sog' — omonmilar? — Are your parents OK?

Katta-kichiklar yaxshimi? - Are elder and younger people Ok?

In Uzbek culture to show more politeness, while asking about family members, people ask as if interlocutor's relatives are their relatives too. First person possessive affixes are used for relative words. Example:

"Opam/akam/amakim/xolam/jiyanim/ukam/singlim yaxshimi?

How is my sister/brother/uncle/aunt/cousin/daughter/son?

This speech etiquette units have meaning as "I am close to you. I am like your relative" in order to show respect towards others.

\section{Conclusions}

To summarize, politeness in various languages is still hot topic that should be investigated more on the purpose of gaining more facts connected with not only linguistics, but also culture, mentality, religion and other values of the nation and realize them cognitively.

We have tried to determine differences and similarities of two nation, Iranian and Uzbek people, in their speech of most common acts — Greetings. 53 Uzbek greetings, 59 Persian greeting phrases analyzed lingua-pragmatically in comparative way.

Some formal phrases in Persian were shown up in Uzbek speech as an informal or neutral one. (e.g. Assalamu alaikum — in Persian - very formal, means: I am a religious person. Therefore, they use "Salam to say hello. In Uzbek, it can be used for both formal and informal speech to show the respect towards interlocutor. Whereas, "Salam" in Uzbek is not so polite, considered to be an informal phrase used among friends and so forth.)

Persian people tend to use etiquette units more (no matter sincerely or not) and debasing $1^{\text {st }}$ person (oneself), praising $2^{\text {nd }}$, even $3^{\text {rd }}$ person could bring misunderstanding for Uzbek people. (in Persian: A: How are you? - B: I am good, because Mr. C is beside me.) But giving high position to $3^{\text {rd }}$ person has happened in Uzbek speech either only in asking about relatives from the speech partner. (e.g. "How is my brother?" in Uzbek, "How is your brother/son.") FSA is dominant in Persian where FTA can sometimes be seen in Uzbek speech. Idiomatic phrases are used to strengthen politeness in both languages.

\section{References:}

1. Romanova, N. N., \& Filippov, A. V. (2009). Slovar': kul'tura rečevogo obščenija; etika, pragmatika, psichologija. Flinta.

2. Levinson, S. C. (1983). Pragmatics Cambridge University Press. Cambridge UK.

3. Shammas, N. A. (2005). Lingua-pragmatic politeness and translatability. Damascus University Journal, 21(3), 4.

4. Leech, G. N. (2016). Principles of pragmatics. Routledge.

5. Wilson, D. (1994), Taped Personal Communication with Wilson, Deirdre, University College London: 14 June 1994.

6. Zhu, J., \& Bao, Y. (2010). The Pragmatic Comparison of Chinese and Western" Politeness" in Cross-cultural Communication. Journal of Language Teaching \& Research, 1(6). doi:10.4304/jltr.1.6.848-851

7. Michael Victory Interests in sinology (Chinese studies) and Hokkien research. www.quora.com

8. Afghari, A., \& Karimnia, A. (2007). A contrastive study of four cultural differences in everyday conversation between English and Persian. Intercultural communication studies, 16(1), 243. 
9. Jibreen, M. A. K. (2010). The speech act of greeting: A theoretical reading. Journal of Kerbala University, 8(1), 1-25.

10. Sahragard, R. (2003). A cultural script analysis of a politeness feature in Persian. 8th PanPacific Association of Applied Linguistics, Japan.

11. Jabbborov, J. (1997). Muomala madaniyati. Muloqot, 5. 39-41. (In Uzbek)

12. Mo'minov, S. M. (2000). O'zbek muloqot xulqining ijtimoiy-lisoniy xususiyatlari. $F F D$ dissertatsiyasi. Farg'ona davlat universiteti. Toshkent. (in Uzbek)

\section{Список литературы:}

1. Romanova N. N., Filippov A. V. Slovar': kul'tura rečevogo obščenija; etika, pragmatika, psichologija. Flinta, 2009.

2. Levinson S. C. Pragmatics Cambridge University Press // Cambridge UK. 1983.

3. Shammas N. A. Lingua-pragmatic politeness and translatability // Damascus University Journal. 2005. V. 21. №3. P. 4.

4. Leech G. N. Principles of pragmatics. Routledge, 2016.

5. Wilson D. Taped Personal Communication with Wilson, Deirdre, University College London: 14 June 1994.

6. Zhu J., Bao Y. The Pragmatic Comparison of Chinese and Western" Politeness" in Crosscultural Communication // Journal of Language Teaching \& Research. 2010. V. 1. №6. doi:10.4304/jitr.1.6.848-851

7. Michael Victory Interests in sinology (Chinese studies) and Hokkien research. www.quora.com

8. Afghari A., Karimnia A. A contrastive study of four cultural differences in everyday conversation between English and Persian // Intercultural communication studies. 2007. V. 16. №1. P. 243.

9. Jibreen M. K. The speech act of greeting: A theoretical reading // Journal of Kerbala University. 2010. V. 8. №1. P. 1-25.

10. Sahragard R. A cultural script analysis of a politeness feature in Persian // 8th Pan-Pacific Association of Applied Linguistics, Japan. 2003.

11. Jabbborov J. Muomala madaniyati. Muloqot, 1997. 5. 39-41. (In Uzbek)

12. Mo'minov S. M. O'zbek muloqot xulqining ijtimoiy-lisoniy xususiyatlari. FFD dissertatsiyasi. Farg'ona davlat universiteti. Toshkent. 2000. (in Uzbek)

Работа поступила

в редакиию 20.07.2019 2.
Принята к публикациии

27.07.2019 2.

Ссылка для циттирования:

Turdieva Kh. Linguapragmatic Analyze of Greetings in Persian and Uzbek Languages // Бюллетень науки и практики. 2019. Т. 5. №9. С. 521-530. https://doi.org/10.33619/2414$2948 / 46 / 63$

Cite as (APA):

Turdieva, Kh. (2019). Linguapragmatic Analyze of Greetings in Persian and Uzbek Languages. Bulletin of Science and Practice, 5(9), 521-530. https://doi.org/10.33619/24142948/46/63 (in Russian). 